Review

\title{
First-Principles Studies of Adsorptive Remediation of Water and Air Pollutants Using Two-Dimensional MXene Materials
}

\author{
Yujuan Zhang *, Ningning Zhang and Changchun Ge * \\ School of Materials Science and Engineering, University of Science and Technology Beijing, \\ Beijing 100083, China; zhangningning.1211@163.com \\ * Correspondence: zhangyujuan@ustb.edu.cn (Y.Z.); ccge@mater.ustb.edu.cn (C.G.)
}

Received: 23 October 2018; Accepted: 12 November 2018; Published: 14 November 2018

check for updates

\begin{abstract}
Water and air pollution is a critical issue across the whole world. Two-dimensional transition metal carbide/nitride (MXene) materials, due to the characteristics of large specific surface area, hydrophilic nature and abundant highly active surficial sites, are able to adsorb a variety of environmental pollutants, and thus can be used for environmental remediation. First-principles method is a powerful tool to investigate and predict the properties of low-dimensional materials, which can save a large amount of experimental costs and accelerate the research progress. In this review, we summarize the recent research progresses of the MXene materials in the adsorptive remediation of environmental pollutants in polluted water and air using first-principles simulations, and try to predict the research direction of MXenes in the adsorptive environmental applications from first-principles view.
\end{abstract}

Keywords: MXene; first-principles; adsorption; environmental remediation

\section{Introduction}

Water and air pollution has been always a critical issue across the whole world. The pollutants exist in a variety of forms, including heavy metal ions, toxic organics, gases, bacterium, and even radionuclides. They can pose significant negative effects on human beings and other living organism. For example, in some cases, they cause serious diseases, and even cancer, to human beings [1]. Among various techniques for the removal of pollutants, such as membrane filtration, precipitation, solvent extraction and ion exchange [2-5], adsorption especially attracts people's attention, since it possesses several advantages, e.g., easy-operation, cost-effective, and also can avoid secondary pollution by generating other harmful substances [6-9]. The adsorbents usually have large specific surface area, and active functionalities for pollutants. Nowadays, activated carbon has been widely used for the removal of industrially discharged pollutants [10].

Since graphene was discovered [11], two-dimensional (2D) materials have been garnering great attentions due to the unique properties different from their bulk counterparts. After graphene, more and more members of the 2D family have been discovered, such as transition metal dichalcogenides (TMD), hexagonal boron nitrides, phosphorenes, etc. [12-14]. These materials have been demonstrated to be of promising applications in diverse areas. In $2011, \mathrm{Ti}_{3} \mathrm{C}_{2}$ layered materials were first synthesized using a hydrofluoric acid (HF) etching process [15]. In the years afterward, more 2D transition metal carbide/nitride (labeled as MXene) materials were synthesized [16-18]. MXenes usually combine the properties of both metals and ceramics, such as high chemical stabilities and high electrical conductivities, behaving as "conductive clays" [19]. MXenes have great potential applications in the energy-storage area, e.g., supercapacitors, and lithium-ion batteries [20-22]. The as-prepared MXenes 
using chemical etching method generally possess hydrophilic nature and abundant highly active functional groups on the surfaces, and therefore are able to effectively adsorb various pollutants.

Experimental studies are usually subject to many factors, e.g., materials, equipment, and costs, and therefore limit the research speed. However, theoretical simulation such as density functional theory (DFT) based first-principles method is an effective approach to analyze and predict the properties of low-dimensional materials. For the studies of the adsorption of pollutants on MXenes, first-principles method can help researchers better predict the promising MXene candidates that can efficiently adsorb specific toxic pollutants, thereby, eliminating the need to conduct experimental studies with unproductive outcomes. Thus, in this regard, first-principles methods can help save time and resources, but give very convincing results.

In this paper, we review the recent research progress of the MXene materials in the adsorptive remediation of environmental pollutants in polluted water and air using first-principles simulations, including heavy metal elements, radionuclides, and gaseous molecules, and try to predict the research direction of MXenes in the adsorptive environmental applications based on first-principles theory. We hope this review can help the theoretical researchers widen their research area, and even accelerate the pace of applying the MXene materials in practical environmental systems.

\section{Brief Introductions to the Development of First-Principles Simulation}

Density functional theory-based first-principles simulation is a quantum mechanical method that obtains electronic structures of materials through resolving Schrödinger equation and further predicts the physical properties of the materials. This method starts from five basic physical constants, i.e., electron mass, electron charge, Planck constant, speed of light, and Boltzmann constant, and does not rely on any empirical constants, and thereby considered as a very accurate approach. With the development of high-throughput computing science, first-principles calculation method has achieved significant development and been widely used to study the physicochemical properties of materials.

The theoretical study of strong correlation systems like transition metals, lanthanides, and actinides-including systems, involves relativistic effects and strong electronic correlation effects that cannot be dealt with by traditional density functional theory. For example, Pacchioni et al. have proved that the adsorption properties of $\mathrm{CO}$ on the $\mathrm{Pt}(100)$ surface can be well explained by taking into account the scalar relativistic effects [23]. The scalar relativistic effect containing the relativistic mass shift and the Darwin term is included in the projector augmented wave pseudopotential in the studies of uranium ion adsorption on MXene materials by Zhang et al. [24,25] In recent years, breakthroughs in the calculation of strong-correlation materials based on density functional theory have been made, such as hybrid density functional method [26], self-consistent field interaction correction [27] and density functional theory plus $U(\mathrm{DFT}+\mathrm{U})$ method [28]. The above methods correct the strong correlation between $5 f$ electrons, making it possible to accurately simulate strong-correlation systems. Hybrid density functional method introduces the non-local Hartree-Fock exchange term in the correlation term, which corrects the deficiency of the traditional density functional theory method in dealing with self-interactions [26]. This method can accurately describe the structures, density of states, and optical band gap properties of insulating materials. Wen et al. accurately described the electronic and structural properties of lanthanide dioxide using the hybrid density functional method [26]. Self-consistent field interaction correction can be regarded as a generalized Hartree-Fock approximation considering the dynamic Coulomb shielding interaction [27]. It is used to eliminate the unreal electronic self-interactions in the band structure theory derived from the local spin density approximation (LSDA). Petit et al. applied this method to the calculation of the ground state electronic structure of the lanthanide nitride [29]. The DFT+U method adds a Hubbard $U$ term to the Hamiltonian, which can correct the strong correlation interaction between electrons. The DFT+U method has been developed into an effective theoretical research tool in dealing with strongly correlated electronic materials. Guo et al. have studied the adsorption properties of $\mathrm{Pb}$ and $\mathrm{Cu}$ on MXenes using DFT+U method [30]. For the metastable problem in DFT+U calculations, 
different approaches such as occupation matrix control (OMC) method [31], U-ramping method [32], quasi-annealing (QA) method [33] and controlled symmetry reduction (CSR) method [28,34] have been developed.

In addition, the first-principles dynamics method combining the first-principles method for solving the Schrödinger equation and the classical molecular dynamics method has gradually become an important theoretical research tool for the simulation of dynamic processes in materials. The biggest difference between the first-principles dynamics method and the classical molecular dynamics method is the way to obtain the interaction between particles. The force in the classical molecular dynamics method is obtained by the potential function, and the first-principle dynamics method is based on the electronic wave function, and the force between the particles is derived by the Hellmann-Feynman theorem [35].

\section{Structures of MXene Materials}

Typically, MXenes can be synthesized from "MAX" matrix phase using a chemical etching process, e.g., hydrofluoric acid (HF), hydrochloric acid ( $\mathrm{HCl})$ combined with lithium fluoride ( $\mathrm{LiF})[17,19]$. The term "MAX" represents the reactant compounds $\mathrm{M}_{n+1} \mathrm{AX}_{n}(n=1,2,3)$, where $\mathrm{M}$ denotes a transition metal element, A stands for a group IIIA or IVA element (A = Al, Ga, In, Si, Ge, Sn, Pb, P, As, $\mathrm{S}$ and $\mathrm{Cd}$ ) and $\mathrm{X}$ is $\mathrm{C}$ or $\mathrm{N}$ element. An example of $\mathrm{MAX}$ is $\mathrm{Ti}_{3} \mathrm{AlC}_{2}$, from which the first MXene material, $\mathrm{Ti}_{3} \mathrm{C}_{2}$, was fabricated [15]. Therefore, the structure of a MXene can be described as $n+1$ layers of $\mathrm{M}$ atoms covering $n$ layers of $\mathrm{X}$ atoms in an $(\mathrm{MX})_{n} \mathrm{M}$ arrangement. So far, at least three different MXenes, $M_{2} X, M_{3} X_{2}$ and $M_{4} X_{3}$, have been confirmed [17,22], as shown in Figure 1.

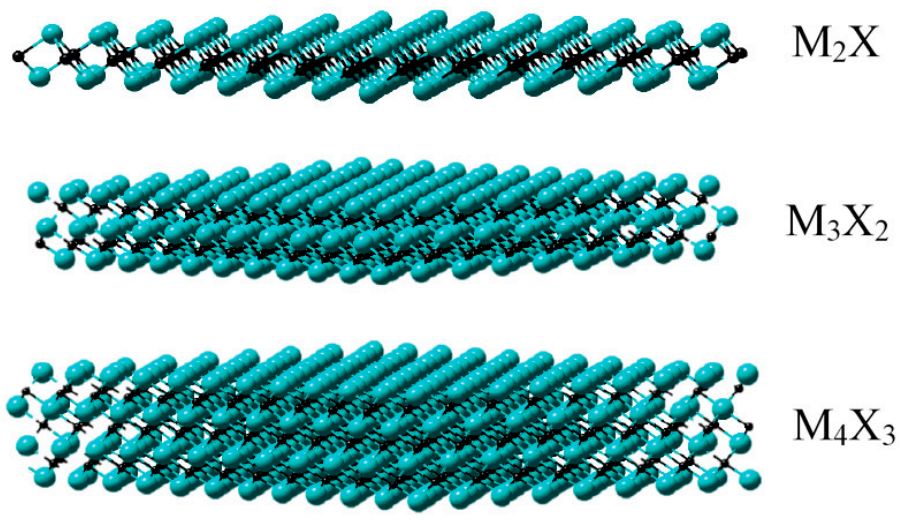

Figure 1. The early reported three different structures of 2D transition metal carbide/nitride (MXenes) (non-terminated): $\mathrm{M}_{2} \mathrm{X}, \mathrm{M}_{3} \mathrm{X}_{2}$ and $\mathrm{M}_{4} \mathrm{X}_{3}$. Reprinted from Ref. [22] with permission. Copyright 2017 Macmillan Publishers Limited. (Color online).

MXenes synthesized from chemical etching method usually possess various surficial functional groups, the most common ones of which are oxygen $(-\mathrm{O})$, hydroxyl $(-\mathrm{OH})$ or fluorine $(-\mathrm{F})[36-38]$. Therefore, the chemical formula of MXene is generally written as " $\mathrm{M}_{n+1} \mathrm{X}_{n} \mathrm{~T}_{\mathrm{x}}$ ", where T denotes the surficial functional groups. For example, $\mathrm{Ti}_{3} \mathrm{C}_{2} \mathrm{MXene} \mathrm{synthesized} \mathrm{from} \mathrm{chemical} \mathrm{etching} \mathrm{method} \mathrm{can}$ at least have the following three formulae: $\mathrm{Ti}_{3} \mathrm{C}_{2}(\mathrm{OH})_{2}, \mathrm{Ti}_{3} \mathrm{C}_{2} \mathrm{O}_{2}$ and $\mathrm{Ti}_{3} \mathrm{C}_{2} \mathrm{~F}_{2}$, as shown in Figure 2. The species and quantities of these terminal groups are highly dependent on the synthesis process. As is known, hydrophilic nature facilitates adsorption for polar or ionic pollutants, i.e, the -F group is unfavorable for adsorption, which will be discussed in the following part.

Employing chemical vapor deposition method, MXenes without surficial functional groups have also been successfully synthesized, such as $\mathrm{Mo}_{2} \mathrm{C}, \mathrm{WC}$, and $\mathrm{TaC}$ [39]. Since the exposed unterminated metal atoms are highly reactive, these MXenes are prone to combining with other substances, and thus very suitable to be adsorbents. First-principles calculations have confirmed this characteristic, which will be seen in the following text. 
(a)

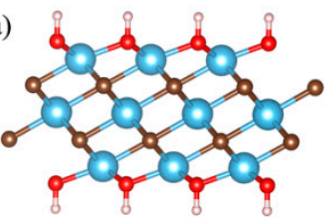

(c)

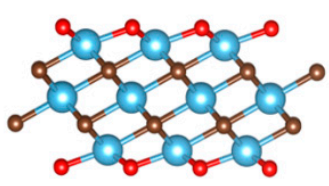

(e)

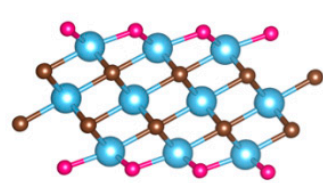

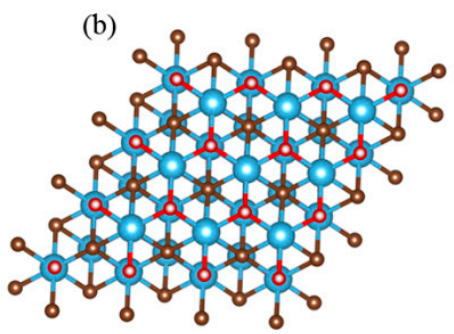
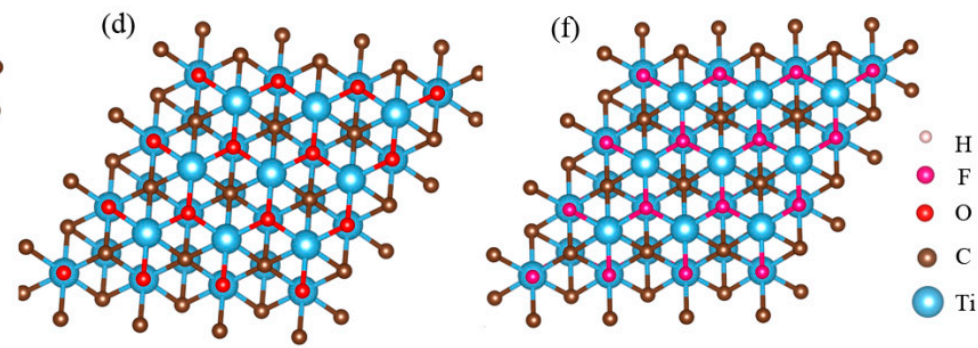

Figure 2. The structure of $\mathrm{Ti}_{3} \mathrm{C}_{2}$ nanosheets with different functional groups from side and top views: $(\mathbf{a}, \mathbf{b}) \mathrm{Ti}_{3} \mathrm{C}_{2}(\mathrm{OH})_{2} ;(\mathbf{c}, \mathbf{d}) \mathrm{Ti}_{3} \mathrm{C}_{2} \mathrm{O}_{2}$ and $(\mathbf{e}, \mathbf{f}) \mathrm{Ti}_{3} \mathrm{C}_{2} \mathrm{~F}_{2}$. (Color online).

\section{First-Principles Progress of Adsorption of Pollutants on MXenes}

Subject to calculation resources, first-principles method is more suitable for studying the adsorption behaviors of small molecular adsorbates on MXenes, but is difficult for large and complex species. For example, experiments have confirmed the excellent adsorption behaviors of organic dyes [40-43] or even bacterium [44-46] on MXenes. However, first-principles based theoretical studies for the adsorption behaviors of these complex systems on MXenes are not yet reported.

According to the types of the pollutants adsorbates in water and air reported in literature, we will make discussions on heavy metal elements, radionuclides, and gaseous molecules.

\subsection{Heavy Metal Elements Adsorption}

Heavy metal elements can exist in cationic, anionic and electrically neutral forms. Heavy metal ions generally exist in water bodies, such as rivers or lakes. They can cause serious threat to human beings and other animals. Typical toxic heavy metal elements include $\mathrm{Pb}, \mathrm{Cr}, \mathrm{Hg}, \mathrm{Cd}$ and $\mathrm{Cu}$. World Health Organization (WHO) has made clear statements for the upper limits of heavy metal elements in drinking water, called WHO's Drinking Water Standards (set up in Geneva in 1993). For example, the upper limit of $\mathrm{Pb}$ in drinking water is $10 \mu \mathrm{g} / \mathrm{L}$, and the upper limit of $\mathrm{Cd}$ is $3 \mu \mathrm{g} / \mathrm{L}$. Many researchers have studied the adsorption behaviors of heavy metal elements on MXenes using first-principles method, which agree well with the experimental results.

$\mathrm{Pb}(\mathrm{II})$ is the first heavy metal ion confirmed to be effectively adsorbed on MXenes by first-principles method. Peng et al. reported that $\mathrm{NaOH}$-treated $\mathrm{Ti}_{3} \mathrm{C}_{2}$ MXene material $\mathrm{Ti}_{3} \mathrm{C}_{2}(\mathrm{OH} / \mathrm{ONa})_{x} \mathrm{~F}_{2-x}$ has excellent adsorptive ability for $\mathrm{Pb}(\mathrm{II})$, and interpreted it based on first-principles theory [47]. The adsorption chemical equations are:

$$
\begin{aligned}
& \mathrm{Ti}_{3} \mathrm{C}_{2}(\mathrm{OH})_{2}+m \mathrm{~Pb}\left(\mathrm{NO}_{3}\right)_{2} \rightarrow \mathrm{Ti}_{3} \mathrm{C}_{2}\left(\mathrm{O}_{2} \mathrm{H}_{2-2 m} \mathrm{~Pb}_{m}\right)+2 m \mathrm{HNO}_{3} \\
& \mathrm{Ti}_{3} \mathrm{C}_{2}(\mathrm{ONa})_{2}+m \mathrm{~Pb}\left(\mathrm{NO}_{3}\right)_{2} \rightarrow \mathrm{Ti}_{3} \mathrm{C}_{2}\left(\mathrm{O}_{2} \mathrm{H}_{2-2 m} \mathrm{~Pb}_{m}\right)+2 m \mathrm{NaNO}_{3}
\end{aligned}
$$

i.e., ion exchange reactions occur between $\mathrm{Pb}$ and $\mathrm{H} / \mathrm{Na}$ atoms. Electron localization function (ELF) calculations show that the mechanism of adsorption includes two aspects: $\mathrm{Pb}$ atom forms strong chemical bonds with oxygen atoms (hydroxyls losing $\mathrm{H}$ atoms), and at the same time with the surrounding hydroxyl groups, as in shown in Figure 3. This mechanism can be vividly described as the $\mathrm{Pb}$ atom being trapped by two underneath oxygen atoms and eight surrounding hydroxyl groups. First-principles calculation also predicts that the sites of hydroxyl groups and the types of surficial functional groups significantly affect the adsorption behaviors of $\mathrm{Pb}(\mathrm{II})$ on $\mathrm{Ti}_{3} \mathrm{C}_{2}(\mathrm{OH})_{2}$ 
MXene [48]. The hydroxyl groups on top of the titanium atoms have larger adsorption energies than other adsorbed structures, implying stronger ability for the adsorption of $\mathrm{Pb}$ (II). Surficial fluorine groups have negative effects on the adsorption efficiency, while the addition of $\mathrm{Li}, \mathrm{Na}$, and $\mathrm{K}$ atoms facilitates the adsorption. Moreover, the coverage of $\mathrm{Pb}$ (II) on the MXene surface has important effects on the adsorption energy: the adsorption energy decreases with increasing the coverage, i.e., with increasing the adsorbed $\mathrm{Pb}$ atoms, further adsorption ability of the MXene is weakened. When the coverage is smaller than 1/9 monolayer (ML), the MXene exhibits strong adsorption ability for $\mathrm{Pb}$ (II) ions (adsorption energy greater than $-1 \mathrm{eV}$ ). Peng et al. have also studied the adsorption behaviors of $\mathrm{Pb}(\mathrm{II})$ on different $\mathrm{MXenes}$ with a general form $\mathrm{M}_{2} \mathrm{X}(\mathrm{OH})_{2}(\mathrm{M}=\mathrm{Sc}, \mathrm{Ti}, \mathrm{V}, \mathrm{Cr}, \mathrm{Zr}, \mathrm{Nb}, \mathrm{Mo}, \mathrm{Hf}, \mathrm{Ta}$, and $\mathrm{X}=\mathrm{C}$ or $\mathrm{N})$ using first-principles theory [49]. The results indicate that only $\mathrm{Zr}_{2} \mathrm{C}\left(\mathrm{O}_{2} \mathrm{H}_{2-2 x} \mathrm{~Pb} \mathrm{~b}_{x}\right)$ and $\mathrm{Sc}_{2} \mathrm{C}\left(\mathrm{O}_{2} \mathrm{H}_{2-2 x} \mathrm{~Pb}_{x}\right)$ have positive formation energies, i.e., $\mathrm{Sc} \mathrm{C}_{2} \mathrm{C}(\mathrm{OH})_{2}$ and $\mathrm{Zr}_{2} \mathrm{C}(\mathrm{OH})_{2} \mathrm{MXenes}$ are not suitable for $\mathrm{Pb}(\mathrm{II})$ removal. All adsorption products $\mathrm{M}_{2} \mathrm{~N}\left(\mathrm{O}_{2} \mathrm{H}_{2-2 x} \mathrm{~Pb}_{x}\right)$ have negative formation energies, and more negative than their carbide counterparts, indicating the $\mathrm{M}_{2} \mathrm{~N}(\mathrm{OH})_{2} \mathrm{MXene}$ has stronger $\mathrm{Pb}$ adsorption ability than $\mathrm{M}_{2} \mathrm{C}(\mathrm{OH})_{2} \mathrm{MXene}$. These results are of great significance for guiding practical applications.

(a)

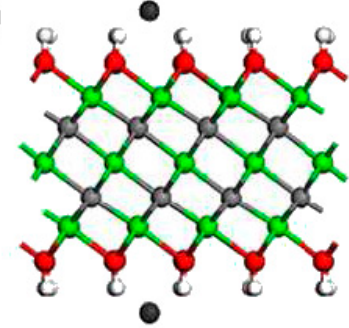

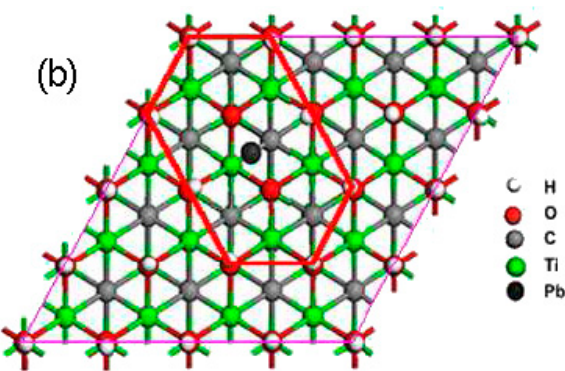

Figure 3. The sketch map of $\mathrm{Ti}_{3} \mathrm{C}_{2}\left(\mathrm{O}_{2} \mathrm{H}_{2-2 m} \mathrm{~Pb}_{\mathrm{m}}\right)$ after $\mathrm{Pb}$ atom replaces two $\mathrm{H}$ atoms: (a) the side view; (b) the top view. Reprinted from Ref. [47] with permission. Copyright 2014 American Chemical Society. (Color online).

Similar to $\mathrm{Pb}$ (II), first-principles calculations show that alkaline intercalated $\mathrm{Ti}_{3} \mathrm{C}_{2}$ MXene can also effectively adsorb a series of other divalent heavy metal ions including $\mathrm{Cu}, \mathrm{Zn}, \mathrm{Pd}, \mathrm{Cd}$ [48]. The adsorption chemical reaction of divalent heavy metals $\mathrm{Y}$ (in nitrate form) can be written as $\mathrm{Ti}_{3} \mathrm{C}_{2}(\mathrm{OH})_{2}+m \mathrm{Y}\left(\mathrm{NO}_{3}\right)_{2} \rightarrow \mathrm{Ti}_{3} \mathrm{C}_{2}\left(\mathrm{O}_{2} \mathrm{H}_{2-2 m} \mathrm{Y}_{m}\right)_{2}+2 m \mathrm{HNO}_{3}$. When the coverage is smaller than $1 / 9$ mololayer (ML), adsorption energies for all four heavy metal elements are greater than $-1 \mathrm{eV}$, i.e., all the ions can be effectively adsorbed on $\mathrm{Ti}_{3} \mathrm{C}_{2}(\mathrm{OH})_{2}$ MXene. $\mathrm{Ti}_{3} \mathrm{C}_{2} \mathrm{~T}_{\mathrm{x}}$ MXene has been experimentally confirmed to be an effective adsorbent for $\mathrm{Cu}(\mathrm{II})$ ion [50]. Additionally, it is also experimentally reported that $\mathrm{Ti}_{3} \mathrm{C}_{2} \mathrm{~T}_{\mathrm{x}}$ MXene can effectively adsorb $\mathrm{Ba}$ (II) ion [51,52], yet lack of first-principles analysis.

Except for the above positively charged heavy metal ions, MXenes have also been confirmed to adsorb negatively charged heavy metal ions. For example, experimental studies have shown that $\mathrm{Ti}_{3} \mathrm{C}_{2} \mathrm{~T}_{x}$ MXene possesses a high purification capacity for $\mathrm{Cr}_{2} \mathrm{O}_{7}{ }^{2-}$ ions in water [53,54]. At low $\mathrm{pH}$, the adsorption of $\mathrm{Cr}(\mathrm{VI})$ on $\mathrm{Ti}_{3} \mathrm{C}_{2} \mathrm{~T}_{\mathrm{x}}$ is attributed to the electrostatic attraction between positively charged surface of MXene and negatively charged $\mathrm{Cr}_{2} \mathrm{O}_{7}{ }^{2-}$ ion. Along with the adsorption, the MXene can reduce $\mathrm{Cr}$ (IV) to $\mathrm{Cr}$ (III) at the same time. However, there is no related first-principles analysis regarding the adsorption of negatively charged heavy metal ions on MXenes yet.

Besides the charged heavy metal ions, MXenes have also been shown to be effective adsorbents for free non-ionic heavy metal atoms based on first-principles theory. Guo et al. have systematically investigated the adsorption behaviors of non-ionic $\mathrm{Pb}$ and $\mathrm{Cu}$ atoms on different MXenes using $\mathrm{DFT}+\mathrm{U}$ method, including $\mathrm{Ti}_{3} \mathrm{C}_{2}, \mathrm{~V}_{2} \mathrm{C}_{1}$ and $\mathrm{Ti}_{2} \mathrm{C}_{1}$ MXenes with bare, $\mathrm{H}, \mathrm{OH}$, and $\mathrm{F}$ terminations [30]. The results show that surface terminations significantly influence the adsorption ability for $\mathrm{Pb}$ and $\mathrm{Cu}$ atoms. All the MXenes can effectively adsorb $\mathrm{Pb}$ atoms with binding energy larger than $1 \mathrm{eV}$ 
except $\mathrm{F}$ terminated ones, and only bare and $\mathrm{OH}$ terminated MXenes can effectively adsorb $\mathrm{Cu}$ atoms. The mechanism of the adsorption is related to the complex interactions between the adatoms $(\mathrm{Pb}$ and $\mathrm{Cu}$ ) and MXene atoms. Based on first-principles calculations, $\mathrm{Ti}_{2} \mathrm{C}(\mathrm{OH})_{2}$ and $\mathrm{Ti}_{3} \mathrm{C}_{2}(\mathrm{OH})_{2} \mathrm{MXenes}$ are also shown to effectively adsorb free non-ionic $\mathrm{Au}$ atoms with adsorption energy greater than $3 \mathrm{eV}$ [55]. The replacement of $\mathrm{OH}$ group by $\mathrm{O}$ and $\mathrm{F}$ terminations can significantly weaken the adsorption ability. Up to now, no experimental studies have been carried out for the adsorption of free heavy metal atoms on MXenes.

In short, first-principles studies have confirmed the excellent adsorption behaviors of MXenes for positively charged heavy metal ions and free non-ionic heavy metal atoms. For both types of heavy metal elements, surface terminations are found to significantly affect the adsorption behaviors, and generally speaking, -F group can reduce the adsorption ability of the MXenes.

\subsection{Radionuclide Elements Adsorption}

With the increase in nuclear energy utilization, nuclear waste pollution is becoming a challenging environmental concern because the contamination of the radionuclides can be significant hazards even at trace amounts due to their long-term radiological and chemical toxicities. Regarding the charged state, radionuclide elements can exist in different forms, e.g., cationic $\mathrm{UO}^{2+}$, anionic $\mathrm{TeO}_{4}{ }^{2-}$, and neutral Xe. Up to now, only cationic $\mathrm{UO}^{2+}$ has been studied for the adsorption behaviors on MXenes.

Titanium carbide $\mathrm{Ti}_{3} \mathrm{C}_{2} \mathrm{~T}_{\mathrm{x}}$ is the first MXene material predicted to be an ideal adsorbent for radionuclide purification by Zhang et al. [25]. First-principles studies have shown that hydrated uranyl cation $\left[\mathrm{UO}_{2}\left(\mathrm{H}_{2} \mathrm{O}\right)_{5}\right]^{2+}$ can be effectively adsorbed by $\mathrm{Ti}_{3} \mathrm{C}_{2}(\mathrm{OH})_{2} \mathrm{MXene}$ in aqueous solution. Uranyl preferentially adsorbs as a bidentate inner-sphere adsorption configuration coordinated to $\mathrm{OH}$ groups on the MXene surface. In this configuration, penta-coordinated uranyl species removes two coordinated water ligands and binds to two surface $\mathrm{O}$ atoms deprotonated from hydroxyl groups in activated Ti sites, forming a bidentate coordinated complex $\mathrm{TiO}_{2}-\mathrm{UO}_{2}\left(\mathrm{H}_{2} \mathrm{O}\right)_{3}$, as shown in Figure 4 . Besides the U-O chemical bonds, hydrogen bonds between the two axial $\mathrm{O}$ atoms of the uranyl and the terminated $\mathrm{H}$ atoms on the MXene surface also contribute to the adsorption interactions. When coordinated by the anionic ligands such as $\mathrm{OH}^{-}, \mathrm{Cl}^{-}$and $\mathrm{NO}_{3}{ }^{-}$, the uranyl species can also be strongly adsorbed by the $\mathrm{Ti}_{3} \mathrm{C}_{2}(\mathrm{OH})_{2} \mathrm{MXene}$. Ab initio molecular dynamical calculations for the bidentate adsorption configuration of $\mathrm{TiO}_{2}-\mathrm{UO}_{2}\left(\mathrm{H}_{2} \mathrm{O}\right)_{3}$ in ambient water show that the water molecules do not have negative effects on the adsorption. Based on the stable adsorption configuration, the theoretical adsorption capacity is calculated to be as high as $595.3 \mathrm{mg} / \mathrm{g}$ for $\left[\mathrm{UO}_{2}\left(\mathrm{H}_{2} \mathrm{O}\right)_{5}\right]^{2+}$ species.
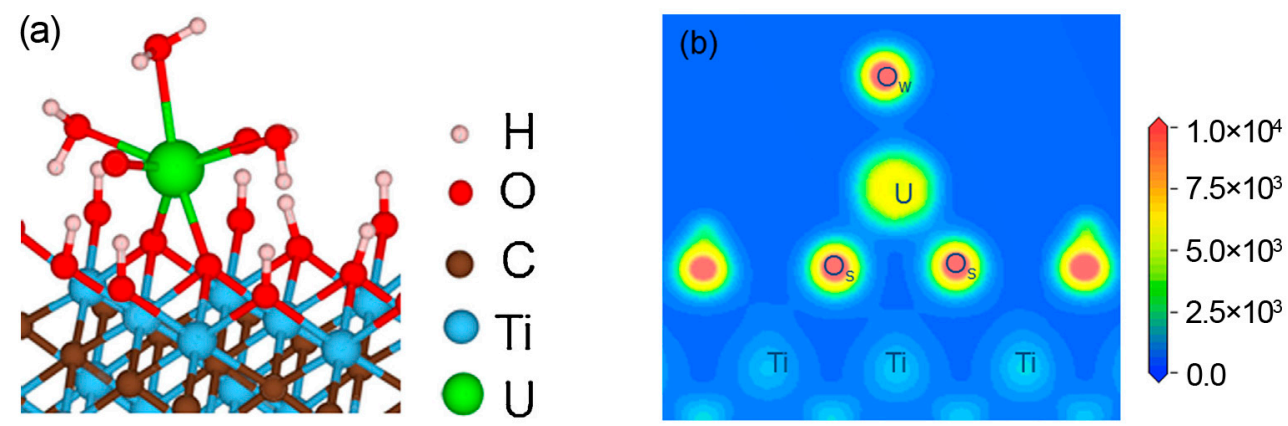

Figure 4. (a) Bidentate inner-sphere adsorption configuration of uranium ion on $\mathrm{Ti}_{3} \mathrm{C}_{2}(\mathrm{OH})_{2}$ nanosheets; (b) Charge density distribution of the adsorption structure by density functional theory (DFT) simulations. Reprinted from Ref. [18] with permission. Copyright 2016 Elsevier B.V. (Color online).

Wang et al. experimentally confirmed the strong adsorption ability of $\mathrm{V}_{2} \mathrm{CT}_{\mathrm{x}}$ MXene for uranyl species and analyzed the results with the first-principles theory [56]. The most energetically favorable adsorption configuration is the bidentate inner-sphere adsorption configuration, where 
penta-coordinated uranyl species removes two coordinated water ligands and forms chemical bonds with two surface $\mathrm{O}$ atoms deprotonated from hydroxyl groups, forming a $\mathrm{VO}_{2}-\mathrm{UO}_{2}\left(\mathrm{H}_{2} \mathrm{O}\right)_{3}$ complex, which is very similar to the situation of $\mathrm{Ti}_{3} \mathrm{C}_{2}(\mathrm{OH})_{2}$. To further clarify the adsorption behaviors of uranyl on $\mathrm{V}_{2} \mathrm{C}$ MXene, the adsorption properties of $\mathrm{V}_{2} \mathrm{C}(\mathrm{OH})_{2}$ nanosheets for uranyl ions with different ligands in the general form $\left[\mathrm{UO}_{2}\left(\mathrm{~L}_{1}\right)_{x}\left(\mathrm{~L}_{2}\right)_{y}\left(\mathrm{~L}_{3}\right)_{z}\right]^{\mathrm{n}}\left(\mathrm{L}_{1}, \mathrm{~L}_{2}\right.$ and $\mathrm{L}_{3}$ stand for $\mathrm{H}_{2} \mathrm{O}, \mathrm{OH}$ and $\left.\mathrm{CO}_{3}\right)$ are studied by Zhang et al. [24]. The results show that all the uranyl species can bind strongly with $\mathrm{V}_{2} \mathrm{C}(\mathrm{OH})_{2}$ nanosheets with high adsorption energies greater than $3 \mathrm{eV}$. Among the studied uranyl species, aquouranyl $\left[\mathrm{UO}_{2}\left(\mathrm{H}_{2} \mathrm{O}\right)_{5}\right]^{2+}$ bonds the strongest to the hydroxylated $\mathrm{V}_{2} \mathrm{C}$ nanosheet. It is also found that the terminated $-\mathrm{F}$ groups on $\mathrm{V}_{2} \mathrm{C}$ nanosheets could weaken the adsorption capability for uranyl ions, which is very similar to the results of heavy metal elements adsorption on MXenes.

In short, first-principles studies have confirmed the strong adsorption ability of hydroxylated MXenes for uranyl species $\mathrm{UO}_{2}{ }^{2+}$. The main adsorption mechanism is the chemical interaction between the $\mathrm{U}$ atom and two $\mathrm{O}$ atoms deprotonated from hydroxyl groups on the MXene surface.

\subsection{Gaseous Pollutants Adsorption}

Industry discharged gaseous pollutants are becoming a critical issue, including toxic inorganic gases, and volatile organic compounds (VOCs). They can cause serious diseases to the respiratory system, and further other systems, of human beings. Several first-principles studies have been carried out on gaseous pollutants adsorption using MXenes, including $\mathrm{NH}_{3}, \mathrm{SO}_{2}$ and $\mathrm{CO}_{2}$.

$\mathrm{Yu}$ et al. have investigated the adsorption behaviors of a series of gas molecules $\left(\mathrm{NH}_{3}, \mathrm{H}_{2}, \mathrm{CH}_{4}\right.$, $\mathrm{CO}, \mathrm{CO}_{2}, \mathrm{~N}_{2}, \mathrm{NO}_{2}$ and $\mathrm{O}_{2}$ ) on monolayer $\mathrm{Ti}_{2} \mathrm{CO}_{2} \mathrm{MXene}$, and found only $\mathrm{NH}_{3}$ could be chemisorbed on the monolayer $\mathrm{Ti}_{2} \mathrm{CO}_{2}$ as compared with other gas molecules, as seen in Figure 5a [57]. Calculations show that $\mathrm{N}-\mathrm{Ti}$ chemical interaction is the main adsorption mechanism. The adsorption energy of $\mathrm{NH}_{3}$ on $\mathrm{Ti}_{2} \mathrm{CO}_{2}$ is $-0.37 \mathrm{eV}$. This intermediate energy implies that $\mathrm{Ti}_{2} \mathrm{CO}_{2}$ is a promising recyclable material for $\mathrm{NH}_{3}$ purification as it could easily release $\mathrm{NH}_{3}$. Furthermore, the electrical conductivity of $\mathrm{Ti}_{2} \mathrm{CO}_{2}$ is enhanced significantly after the adsorption of $\mathrm{NH}_{3}$, indicating $\mathrm{Ti}_{2} \mathrm{CO}_{2}$ could be a potential $\mathrm{NH}_{3}$ sensor with high sensitivity, as shown in Figure 5b. Additionally, the adsorption of $\mathrm{NH}_{3}$ on $\mathrm{Ti}_{2} \mathrm{CO}_{2}$ can be further enhanced by applying strain on the nanosheet. Xiao et al. further studied the adsorption behaviors of $\mathrm{NH}_{3}$ on a series of O-terminated semiconducting MXenes with the general form $\mathrm{M}_{2} \mathrm{CO}_{2}$ ( $\mathrm{M}=\mathrm{Sc}$, Ti, $\mathrm{Zr}$, and $\left.\mathrm{Hf}\right)$ using first-principles simulations [58]. The results show that $\mathrm{NH}_{3}$ could be strongly adsorbed on all four $\mathrm{M}_{2} \mathrm{CO}_{2}$ MXenes with apparent charge transfer, which renders them the potential candidates as the $\mathrm{NH}_{3}$ sensor or capturer. In particular, the $\mathrm{NH}_{3}$ could be released by tuning the number of the electrons injected into $\mathrm{M}_{2} \mathrm{CO}_{2}$ MXenes. These results are very informative for practical applications of $\mathrm{M}_{2} \mathrm{CO}_{2}$ MXenes as $\mathrm{NH}_{3}$ sensors. 


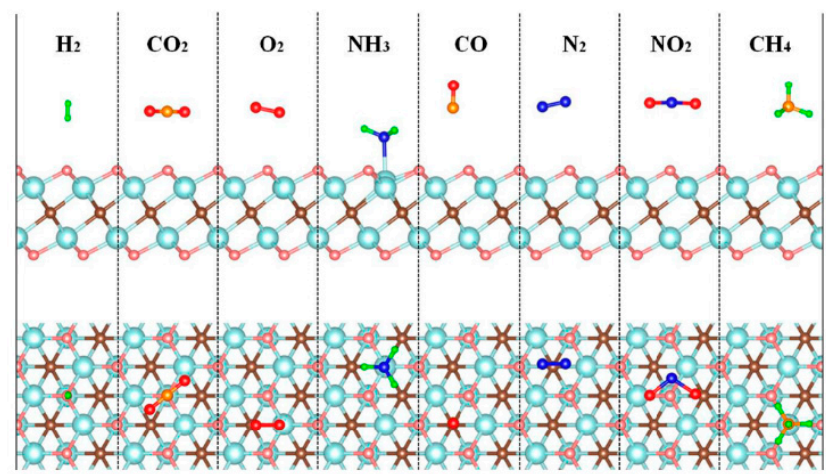

(a)

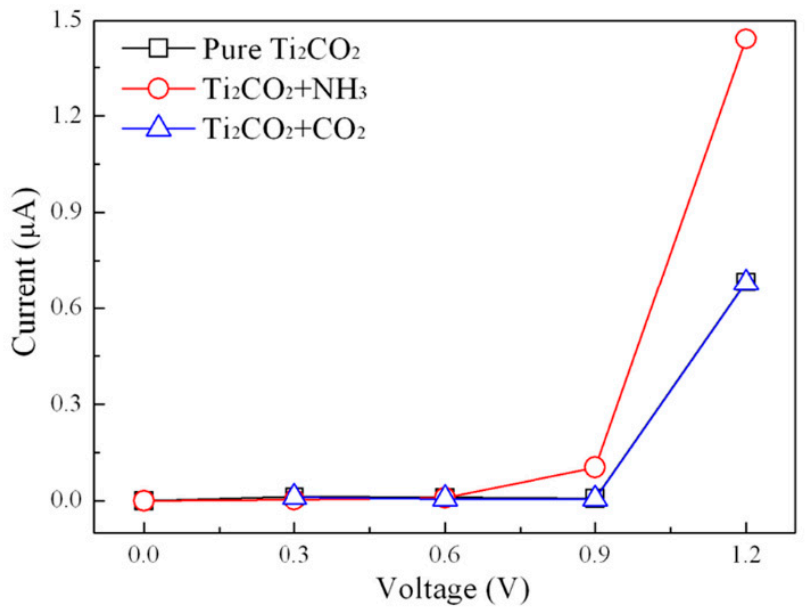

(b)

Figure 5. (a) A schematic illustration of $\mathrm{Ti}_{2} \mathrm{CO}_{2}$-based sensor for detecting $\mathrm{NH}_{3}$ molecule; (b) The currentvoltage (I-V) relations before and after the adsorption of $\mathrm{NH}_{3}$ or $\mathrm{CO}_{2}$ molecule on monolayer $\mathrm{Ti}_{2} \mathrm{CO}_{2}$. Reprinted from Ref. [57] with permission. Copyright 2015 American Chemical Society. (Color online).

Going along with the similar thinking, toxic gaseous $\mathrm{SO}_{2}$ adsorption on O-terminated $\mathrm{M}_{2} \mathrm{CO}_{2}$ ( $\mathrm{M}=\mathrm{Sc}, \mathrm{Hf}, \mathrm{Zr}$, and $\mathrm{Ti}$ ) monolayers has also been studied based on first-principles calculations by Ma et al. [59]. It is found that $\mathrm{Sc}_{2} \mathrm{CO}_{2}$ is the most preferred monolayer for $\mathrm{SO}_{2}$ molecules adsorption with suitable adsorption strength (adsorption energy $-0.646 \mathrm{eV}$ ) compared to other monolayers. The S-Sc chemical bonds are the main adsorption mechanism. Similar to the adsorption of $\mathrm{NH}_{3}$ on $\mathrm{Ti}_{2} \mathrm{CO}_{2}$, the adsorption strength of $\mathrm{SO}_{2}$ on $\mathrm{Sc}_{2} \mathrm{CO}_{2}$ can be further enhanced by applying strains on the nanosheet; and the conductivity of $\mathrm{Sc}_{2} \mathrm{CO}_{2}$ increases with the adsorption of $\mathrm{SO}_{2}$. It is noted that electric field has significant influence on the adsorption behaviors of $\mathrm{SO}_{2}$ on $\mathrm{Sc}_{2} \mathrm{CO}_{2}$ : negative electric field facilitate the adsorption, while positive electric field weakens it (positive direction is the direction from the unadsorbed side to the adsorbed side). This characteristic is very meaningful for the applications of sensors or recycling use as adsorbent materials.

Morales-Garcia et al. first-principles calculated the adsorption behaviors of $\mathrm{CO}_{2}$ on unterminated $\mathrm{M}_{2} \mathrm{C}(\mathrm{M}=\mathrm{Ti}, \mathrm{Zr}, \mathrm{Hf}, \mathrm{V}, \mathrm{Nb}, \mathrm{Ta}, \mathrm{Cr}, \mathrm{Mo}, \mathrm{W}) \mathrm{M}$ Xenes and found that these bare MXenes can effectively adsorb $\mathrm{CO}_{2}$ even at low $\mathrm{CO}_{2}$ partial pressures and high temperatures, thus can act as very promising candidates for carbon dioxide capture, storage, and activation [60]. The adsorption mechanism involves complex interactions between $\mathrm{CO}_{2}$ molecules and the MXenes, and is dependent on the species of MXenes. Since $\mathrm{CO}_{2}$ is considered chemically inert, this result provides strong evidence that bare MXenes are very reactive for adsorbing pollutant species.

In short, O-terminated semiconducting $\mathrm{M}_{2} \mathrm{CO}_{2}$ MXenes exhibit reversible adsorption behaviors towards $\mathrm{NH}_{3}$ and $\mathrm{SO}_{2}$, and thus can act as gas sensors or adsorbents. Chemical bonds between the gas molecules and the $\mathrm{M}$ atoms of the MXenes are the main adsorption mechanism. 


\section{Summary and Outlook}

First-principles calculations have shown that the MXenes, i.e., 2D transition metal carbides/nitrides display very encouraging performances in adsorptive remediation for various pollutants in polluted water and air, including heavy metal elements, radionuclides and gaseous pollutants. Different mechanisms contribute to different adsorption systems. For clarity, the MXene adsorbents and pollutant adsorbates, together with the main adsorption interactions, are summarized and displayed in Table 1. Experimental studies have confirmed some of the theoretical results. However, there are still several open questions that need to be addressed from first-principles view.

Table 1. A list of MXene adsorbents and pollutant adsorbates and their main adsorption interactions by first-principles studies.

\begin{tabular}{|c|c|c|c|}
\hline MXene & Adsorbate & $\begin{array}{l}\text { Main Adsorption } \\
\text { Interaction }\end{array}$ & Reference \\
\hline $\mathrm{Ti}_{3} \mathrm{C}_{2}(\mathrm{OH})_{2}$ & $\begin{array}{c}\mathrm{M}_{\mathrm{ad}}(\mathrm{II})\left(\mathrm{M}_{\mathrm{ad}}=\mathrm{Pb}, \mathrm{Cu}, \mathrm{Zn},\right. \\
\mathrm{Pd}, \mathrm{Cd})\end{array}$ & $\mathrm{M}_{\mathrm{ad}}-\mathrm{O}$ bonds & {$[47,48]$} \\
\hline $\begin{array}{c}\mathrm{M}_{2} \mathrm{C}(\mathrm{OH})_{2}(\mathrm{M}=\mathrm{Ti}, \mathrm{V}, \mathrm{Cr}, \mathrm{Nb}, \mathrm{Mo}, \mathrm{Hf}, \mathrm{Ta}) \\
\mathrm{M}_{2} \mathrm{~N}(\mathrm{OH})_{2}(\mathrm{M}=\mathrm{Sc}, \mathrm{Ti}, \mathrm{V}, \mathrm{Cr}, \mathrm{Zr}, \mathrm{Nb}, \mathrm{Mo}, \mathrm{Hf}, \mathrm{Ta})\end{array}$ & - & $\mathrm{Pb}-\mathrm{O}$ bonds & [49] \\
\hline $\mathrm{M}_{n+1} \mathrm{C}_{n}\left(\mathrm{Ti}_{3} \mathrm{C}_{2}, \mathrm{~V}_{2} \mathrm{C}_{1}, \mathrm{Ti}_{2} \mathrm{C}_{1}\right)$ & $\mathrm{M}_{\mathrm{ad}}\left(\mathrm{M}_{\mathrm{ad}}=\mathrm{Pb}, \mathrm{Cu}\right)$ & $\begin{array}{l}\mathrm{M}_{\mathrm{ad}}-\mathrm{M} \text { and } \mathrm{M}_{\mathrm{ad}}-\mathrm{C} \\
\quad \text { interactions }\end{array}$ & [30] \\
\hline $\mathrm{Ti}_{2} \mathrm{C}(\mathrm{OH})_{2}, \mathrm{Ti}_{3} \mathrm{C}_{2}(\mathrm{OH})_{2}$ & $\mathrm{Au}$ & $\mathrm{Au}-\mathrm{OH}$ bonds & [55] \\
\hline $\mathrm{Ti}_{3} \mathrm{C}_{2}(\mathrm{OH})_{2}$ & U (IV) & U-O bonds & [25] \\
\hline $\mathrm{V}_{2} \mathrm{C}(\mathrm{OH})_{2}$ & U (IV) & U-O bonds & [24] \\
\hline $\mathrm{M}_{2} \mathrm{CO}_{2}(\mathrm{M}=\mathrm{Sc}, \mathrm{Ti}, \mathrm{Zr}$, and $\mathrm{Hf})$ & $\mathrm{NH}_{3}$ & $\mathrm{~N}-\mathrm{M}$ bonds & {$[57,58]$} \\
\hline $\mathrm{Sc}_{2} \mathrm{CO}_{2}$ & $\mathrm{SO}_{2}$ & S-Sc bonds & [59] \\
\hline $\mathrm{M}_{2} \mathrm{C}(\mathrm{M}=\mathrm{Ti}, \mathrm{Zr}, \mathrm{Hf}, \mathrm{V}, \mathrm{Nb}, \mathrm{Ta}, \mathrm{Cr}, \mathrm{Mo}, \mathrm{W})$ & $\mathrm{CO}_{2}$ & $\begin{array}{l}\mathrm{CO}_{2}-\mathrm{MXene} \text { complex } \\
\text { interactions }\end{array}$ & [60] \\
\hline
\end{tabular}

As discussed in above section, surficially bare MXenes are very reactive and able to adsorb a variety of pollutants species from water and air. At the same time, just because of this high reactivity, bare MXenes are very easy to react with ambient molecules, e.g., water and oxygen molecules $[15,20,61,62]$. These molecules may compete with the pollutant species in the adsorption process, and hinder the MXene materials in practical environmental remediation applications. Therefore, deeper studies of adsorption behaviors of pollutant species on bare MXenes, especially the competing behaviors between the pollutant species and ambient molecules should be conducted.

As we have shown, all the discussed charged heavy metal ions are cations. Since anions, e.g., $\mathrm{Cr}_{2} \mathrm{O}_{7}{ }^{2-}$, are also experimentally reported to be adsorbed by MXenes, deep first-principles studies of the adsorption behaviors of heavy metal anions on MXenes need to be carried out. Especially, regarding nuclides, only one species $\mathrm{UO}_{2}{ }^{2+}$ has been considered, and the adsorption behaviors of other nuclide cations and anions on MXenes are still blank and deserve investigations.

Most VOCs are chemically reactive and toxic to human beings, and experimental studies show that the physical properties of MXenes can be affected by adsorption of some VOC molecules, including ethanol, methanol and acetone, and thus can be used as VOC sensors [63]. Since the family of MXenes has a large number of members, adsorptions of different VOCs on different MXenes should be systematically studied based on first-principles method.

In addition, although MXenes have been shown to be able to adsorb gaseous pollutants, e.g., $\mathrm{NH}_{3}, \mathrm{SO}_{2}$, and $\mathrm{CO}_{2}$ [57-60], there are no related experiments reported yet, which should be conducted to confirm their performances. After all, practical applications are the ultimate purpose of scientific studies.

Author Contributions: Y.Z. and C.G. proposed the review. Y.Z. drafted the manuscript. N.Z. revised the manuscript. C.G. reviewed and proofread the manuscript.

Funding: This work was supported by the National Natural Science Foundation of China (Grant No. 11875004, 11505006, 11604008) and Beijing Municipal Natural Science Foundation (Grant No. 2182042).

Conflicts of Interest: The authors declare no conflict of interests. 


\section{References}

1. Jarup, L. Hazards of heavy metal contamination. Br. Med. Bull. 2003, 68, 167-182. [CrossRef] [PubMed]

2. Fu, F.; Xie, L.; Tang, B.; Wang, Q.; Jiang, S. Application of a novel strategy-Advanced Fenton-chemical precipitation to the treatment of strong stability chelated heavy metal containing wastewater. Chem. Eng. J. 2012, 189, 283-287. [CrossRef]

3. Gu, B.; Ku, Y.; Jardine, P.M. Sorption and binary exchange of nitrate, sulfate, and uranium on an anion-exchange resin. Environ. Sci. Technol. 2004, 38, 3184-3188. [CrossRef] [PubMed]

4. Vandegrift, G.F.; Reed, D.T.; Tasker, I.R. Environmental Remediation: Removing Organic and Metal Ion Pollutants; ACS Symposium Series 509; ACS: Washington, DC, USA, 1992.

5. Zhang, Q.; Wang, N.; Zhao, L.; Xu, T.; Cheng, Y. Polyamidoamine dendronized hollow fiber membranes in the recovery of heavy metal ions. ACS Appl. Mater. Interfaces 2013, 5, 1907-1912. [CrossRef] [PubMed]

6. Wang, S.; Sun, H.; Ang, H.; Tadé, M.O. Adsorptive remediation of environmental pollutants using novel graphene-based nanomaterials. Chem. Eng. J. 2013, 226, 336-347. [CrossRef]

7. Adeyemo, A.A.; Adeoye, I.O.; Bello, O.S. Metal organic frameworks as adsorbents for dye adsorption: Overview, prospects and future challenges. Toxicol. Environ. Chem. 2012, 94, 1846-1863. [CrossRef]

8. Foo, K.Y.; Hameed, B.H. Detoxification of pesticide waste via activated carbon adsorption process. J. Hazard. Mater. 2010, 175, 1-11. [CrossRef] [PubMed]

9. Gupta, S.S.; Bhattacharyya, K.G. Adsorption of heavy metals on kaolinite and montmorillonite: A review. Phys. Chem. Chem. Phys. 2012, 14, 6698-6723. [CrossRef] [PubMed]

10. Fu, F.; Wang, Q. Removal of heavy metal ions from wastewaters: A review. J. Environ. Manag. 2011, 92, 407-418. [CrossRef] [PubMed]

11. Novoselov, K.S.; Geim, A.K.; Morozov, S.V.; Jiang, D.; Zhang, Y.; Dubonos, S.V.; Grigorieva, I.V.; Firsov, A.A. Electric field effect in atomically thin carbon films. Science 2004, 306, 666-669. [CrossRef] [PubMed]

12. Butler, S.Z.; Hollen, S.M.; Cao, L.; Cui, Y.; Gupta, J.A.; Gutierrez, H.R.; Heinz, T.F.; Hong, S.S.; Huang, J.; Ismach, A.F.; et al. Progress, Challenges, and Opportunities in Two-Dimensional Materials Beyond Graphene. ACS Nano 2013, 7, 2898-2926. [CrossRef] [PubMed]

13. Xu, M.; Liang, T.; Shi, M.; Chen, H. Graphene-Like Two-Dimensional Materials. Chem. Rev. 2013, 113, 3766-3798. [CrossRef] [PubMed]

14. Fiori, G.; Bonaccorso, F.; Iannaccone, G.; Palacios, T.; Neumaier, D.; Seabaugh, A.; Banerjee, S.K.; Colombo, L. Electronics based on two-dimensional materials. Nat. Nanotechnol. 2014, 9, 768-779. [CrossRef] [PubMed]

15. Naguib, M.; Kurtoglu, M.; Presser, V.; Lu, J.; Niu, J.; Heon, M.; Hultman, L.; Gogotsi, Y.; Barsoum, M.W. Two-dimensional nanocrystals produced by exfoliation of Ti3AlC2. Adv. Mater. 2011, 23, 4248-4253. [CrossRef] [PubMed]

16. Naguib, M.; Mashtalir, O.; Carle, J.; Presser, V.; Lu, J.; Hultman, L.; Gogotsi, Y.; Barsoum, M.W. Two-dimensional transition metal carbides. ACS Nano 2012, 6, 1322-1331. [CrossRef] [PubMed]

17. Naguib, M.; Mochalin, V.N.; Barsoum, M.W.; Gogotsi, Y. 25th anniversary article: MXenes: A new family of two-dimensional materials. Adv. Mater. 2014, 26, 992-1005. [CrossRef] [PubMed]

18. Anasori, B.; Xie, Y.; Beidaghi, M.; Lu, J.; Hosler, B.C.; Hultman, L.; Kent, P.R.; Gogotsi, Y.; Barsoum, M.W. Two-dimensional, ordered, double transition metals carbides (MXenes). ACS Nano 2015, 9, 9507-9516. [CrossRef] [PubMed]

19. Ghidiu, M.; Lukatskaya, M.R.; Zhao, M.; Gogotsi, Y.; Barsoum, M.W. Conductive two-dimensional titanium carbide/clay/'with high volumetric capacitance. Nature 2014, 516, 78-81. [CrossRef] [PubMed]

20. Hu, Q.; Sun, D.; Wu, Q.; Wang, H.; Wang, L.; Liu, B.; Zhou, A.; He, J. MXene: A new family of promising hydrogen storage medium. J. Phys. Chem. A 2013, 117, 14253-14260. [CrossRef] [PubMed]

21. Lukatskaya, M.R.; Mashtalir, O.; Ren, C.E.; Dall Agnese, Y.; Rozier, P.; Taberna, P.L.; Naguib, M.; Simon, P.; Barsoum, M.W.; Gogotsi, Y. Cation intercalation and high volumetric capacitance of two-dimensional titanium carbide. Science 2013, 341, 1502-1505. [CrossRef] [PubMed]

22. Anasori, B.; Lukatskaya, M.R.; Gogotsi, Y. 2D metal carbides and nitrides (MXenes) for energy storage. Nat. Rev. Mater. 2017, 2, 16098. [CrossRef]

23. Pacchioni, G.; Chung, S.C.; Kru Ger, S.; Ro Sch, N. Is CO chemisorbed on Pt anomalous compared with Ni and Pd? An example of surface chemistry dominated by relativistic effects. Surf. Sci. 1997, 392, $173-184$. [CrossRef] 
24. Zhang, Y.; Zhou, Z.; Lan, J.; Ge, C.; Chai, Z.; Zhang, P.; Shi, W. Theoretical Insights into the Uranyl Adsorption Behavior on Vanadium Carbide MXene. Appl. Surf. Sci. 2017, 426, 572-578. [CrossRef]

25. Zhang, Y.; Lan, J.; Wang, L.; Wu, Q.; Wang, C.; Bo, T.; Chai, Z.; Shi, W. Adsorption of uranyl species on hydroxylated titanium carbide nanosheet: A first-principles study. J. Hazard. Mater. 2016, 308, 402-410. [CrossRef] [PubMed]

26. Wen, X.; Martin, R.L.; Scuseria, G.E.; Rudin, S.P.; Batista, E.R. A Screened Hybrid DFT Study of Actinide Oxides, Nitrides, and Carbides. J. Phys. Chem. C 2013, 117, 13122-13128. [CrossRef]

27. Chantis, A.N.; Albers, R.C.; Jones, M.D. Many-body electronic structure of metallic $\alpha$-uranium. Phys. Rev. B: Condens. Matter 2008, 78, 081101. [CrossRef]

28. Gryaznov, D.; Heifets, E.; Kotomin, E. Ab initio DFT+U study of He atom incorporation into $\mathrm{UO}_{2}$ crystals. Phys. Chem. Chem. Phys. 2009, 11, 7241-7247. [CrossRef] [PubMed]

29. Petit, L.; Svane, A.; Szotek, Z.; Temmerman, W.M.; Stocks, G.M. Groundstate electronic structure of actinide carbides and nitrides. Phys. Rev. B 2009, 30, 1132-1136.

30. Guo, X.; Zhang, X.; Zhao, S.; Huang, Q.; Xue, J. High adsorption capacity of heavy metals on two-dimensional MXenes: An ab initio study with molecular dynamics simulation. Phys. Chem. Chem. Phys. 2016, 18, 228-233. [CrossRef] [PubMed]

31. Dorado, B.; Amadon, B.; Freyss, M.; Bertolus, M. DFT+U calculations of the ground state and metastable states of uranium dioxide. Phys. Rev. B 2009, 79, 235125. [CrossRef]

32. Meredig, B.; Thompson, A.; Hansen, H.A.; Wolverton, C.; Van, D.W.A. Method for locating low-energy solutions within DFT+U. Phys. Rev. B Condens. Matter 2010, 82, 195128. [CrossRef]

33. Geng, H.Y.; Chen, Y.; Kaneta, Y.; Kinoshita, M.; Wu, Q. Interplay of defect cluster and the stability of xenon in uranium dioxide by density functional calculations. Phys. Rev. B Condens. Matter 2010, 82, 4079-4085. [CrossRef]

34. Gryaznov, D.; Heifets, E.; Kotomin, E. The first-principles treatment of the electron-correlation and spin-orbital effects in uranium mononitride nuclear fuels. Phys. Chem. Chem. Phys. 2012, 14, 4482-4490. [CrossRef] [PubMed]

35. Gryaznov, D.; Heifets, E.; Sedmidubsky, D. Density functional theory calculations on magnetic properties of actinide compounds. Phys. Chem. Chem. Phys. 2010, 12, 12273-12278. [CrossRef] [PubMed]

36. Wang, H.; Naguib, M.; Page, K.; Wesolowski, D.J.; Gogotsi, Y. Resolving the Structure of Ti3C2T $\mathrm{x}$ MXenes through Multilevel Structural Modeling of the Atomic Pair Distribution Function. Chem. Mater. 2015, 28, 349-359. [CrossRef]

37. Hope, M.A.; Forse, A.C.; Griffith, K.J.; Lukatskaya, M.R.; Ghidiu, M.; Gogotsi, Y.; Grey, C.P. NMR reveals the surface functionalisation of $\mathrm{Ti}_{3} \mathrm{C}_{2}$ MXene. Phys. Chem. Chem. Phys. 2016, 18, 5099-5102. [CrossRef] [PubMed]

38. Wang, X.; Garnero, C.; Rochard, G.; Magne, D.; Morisset, S.; Hurand, S.; Chartier, P.; Rousseau, J.; Cabioc'H, T.; Coutanceau, $\mathrm{C}$. A new etching environment $\left(\mathrm{FeF}_{3} / \mathrm{HCl}\right)$ for the synthesis of two-dimensional titanium carbide MXenes: A route towards selective reactivity vs. water. J. Mater. Chem. A 2017, 5, 22012-22023. [CrossRef]

39. Xu, C.; Wang, L.; Liu, Z.; Chen, L.; Guo, J.; Kang, N.; Ma, X.; Cheng, H.; Ren, W. Large-area high-quality 2D ultrathin Mo2C superconducting crystals. Nat. Mater. 2015, 14, 1135-1141. [CrossRef] [PubMed]

40. Mashtalir, O.; Cook, K.M.; Mochalin, V.N.; Crowe, M.; Barsoum, M.W.; Gogotsi, Y. Dye adsorption and decomposition on two-dimensional titanium carbide in aqueous media. J. Mater. Chem. A 2014, 2, 14334-14338. [CrossRef]

41. Peng, C.; Yang, X.; Li, Y.; Yu, H.; Wang, H.; Peng, F. Hybrids of two-dimensional $\mathrm{Ti}_{3} \mathrm{C}_{2}$ and $\mathrm{TiO}_{2}$ exposing $\{001\}$ facets toward enhanced photocatalytic activity. ACS Appl. Mater. Interaces 2016, 8, 6051-6060. [CrossRef] [PubMed]

42. Zhou, W.; Zhu, J.; Wang, F.; Cao, M.; Zhao, T. One-step synthesis of Ceria/ $\mathrm{Ti}_{3} \mathrm{C}_{2}$ nanocomposites with enhanced photocatalytic activity. Mater. Lett. 2017, 206, 237-240. [CrossRef]

43. Zheng, W.; Zhang, P.; Tian, W.; Qin, X.; Zhang, Y.; Sun, Z.M. Alkali treated $\mathrm{Ti}_{3} \mathrm{C}_{2} \mathrm{~T}_{\mathrm{x}} \mathrm{MXenes}$ and their dye adsorption performance. Mater. Chem. Phys. 2018, 206, 270-276.

44. Rasool, K.; Helal, M.; Ali, A.; Ren, C.E.; Gogotsi, Y.; Mahmoud, K.A. Antibacterial Activity of $\mathrm{Ti}_{3} \mathrm{C}_{2} \mathrm{~T}_{\mathrm{x}} \mathrm{MXene.}$ ACS Nano 2016, 10, 3674-3684. [CrossRef] [PubMed] 
45. Rasool, K.; Mahmoud, K.A.; Johnson, D.J.; Helal, M.; Berdiyorov, G.R.; Gogotsi, Y. Efficient Antibacterial Membrane based on Two-Dimensional $\mathrm{Ti}_{3} \mathrm{C}_{2} \mathrm{~T}_{\mathrm{x}}$ (MXene) Nanosheets. Sci. Rep. 2017, 7, 1-11. [CrossRef] [PubMed]

46. Jastrzebska, A.; Karwowska, E.; Basiak, D.; Zawada, A.; Ziemkowska, W.; Wojciechowski, T.; Jakubowska, D.; Olszyna, A. Biological Activity and Bio-Sorption Properties of the $\mathrm{Ti}_{2} \mathrm{C}$ Studied by Means of Zeta Potential and SEM. Int. J. Electrochem. Sci. 2017, 12, 2159-2172. [CrossRef]

47. Peng, Q.; Guo, J.; Zhang, Q.; Xiang, J.; Liu, B.; Zhou, A.; Liu, R.; Tian, Y. Unique lead adsorption behavior of activated hydroxyl group in two-dimensional titanium carbide. J. Am. Chem. Soc. 2014, 136, 4113-4116. [CrossRef] [PubMed]

48. Guo, J.; Peng, Q.; Fu, H.; Zou, G.; Zhang, Q. Heavy-metal adsorption behavior of two-dimensional alkalizationintercalated MXene by first-principles calculations. J. Phys. Chem. C 2015, 119, 20923-20930. [CrossRef]

49. Guo, J.; Fu, H.; Zou, G.; Zhang, Q.; Zhang, Z.; Peng, Q. Theoretical interpretation on lead adsorption behavior of new two-dimensional transition metal carbides and nitrides. J. Alloys Compd. 2016, 684, 504-509. [CrossRef]

50. Shahzad, A.; Rasool, K.; Miran, W.; Nawaz, M.; Jang, J.; Mahmoud, K.; Lee, D.S. Two-Dimensional Ti ${ }_{3} C_{2} T_{x}$ MXene Nanosheets for Efficient Copper Removal from Water. ACS Sustain. Chem. Eng. 2017, 5, 11481-11488. [CrossRef]

51. Fard, A.K.; Mckay, G.; Chamoun, R.; Rhadfi, T.; Preud'Homme, H.; Atieh, M.A. Barium removal from synthetic natural and produced water using MXene as two dimensional (2D) nanosheet adsorbent. Chem. Eng. J. 2017, 317, 331-342. [CrossRef]

52. Mu, W.; Du, S.; Yu, Q.; Li, X.; Wei, H.; Yang, Y. Improving barium ion adsorption on two-dimensional titanium carbide by surface modification. Dalton Trans. 2018, 47, 8375-8381. [CrossRef] [PubMed]

53. Ying, Y.; Liu, Y.; Wang, X.; Mao, Y.; Cao, W.; Hu, P.; Peng, X. Two-dimensional titanium carbide for efficiently reductive removal of highly toxic chromium (VI) from water. ACS Appl. Mater. Interfaces 2015, 7, 1795-1803. [CrossRef] [PubMed]

54. Zou, G.; Guo, J.; Peng, Q.; Zhou, A.; Zhang, Q.; Liu, B. Synthesis of urchin-like rutile titania carbon nanocomposites by iron-facilitated phase transformation of MXene for environmental remediation. J. Mater. Chem. A 2016, 4, 489-499. [CrossRef]

55. Yang, J.; Zhang, S.; Ji, J.; Wei, S. Adsorption activities of $\mathrm{O}, \mathrm{OH}, \mathrm{F}$ and $\mathrm{Au}$ on two-dimensional $\mathrm{Ti}_{2} \mathrm{C}$ and $\mathrm{Ti}_{3} \mathrm{C}_{2}$ surfaces. Acta Phys.-Chim. Sin. 2015, 31, 369-376.

56. Wang, L.; Yuan, L.; Chen, K.; Zhang, Y.; Deng, Q.; Du, S.; Huang, Q.; Zheng, L.; Zhang, J.; Chai, Z. Loading actinides in multilayered structures for nuclear waste treatment: The first case study of uranium capture with vanadium carbide MXene. ACS Appl. Mater. Interfaces 2016, 8, 16396-16403. [CrossRef] [PubMed]

57. Yu, X.; Li, Y.; Cheng, J.; Liu, Z.; Li, Q.; Li, W.; Yang, X.; Xiao, B. Monolayer $\mathrm{Ti}_{2} \mathrm{CO}_{2}$ : A promising candidate for $\mathrm{NH}_{3}$ sensor or capturer with high sensitivity and selectivity. ACS Appl. Mater. Interfaces 2015, 7, 13707-13713. [CrossRef] [PubMed]

58. Xiao, B.; Li, Y.; Yu, X.; Cheng, J. MXenes: Reusable materials for $\mathrm{NH}_{3}$ sensor or capturer by controlling the charge injection. Sens. Actuators B Chem. 2016, 235, 103-109. [CrossRef]

59. Ma, S.; Yuan, D.; Jiao, Z.Y.; Wang, T.X.; Dai, X. Monolayer $\mathrm{Sc}_{2} \mathrm{CO}_{2}$ : A Promising Candidate as $\mathrm{SO}_{2}$ Gas Sensor or Capturer. J. Phys. Chem. C 2017, 121, 24077-24084. [CrossRef]

60. Morales-Garcia, A.; Fernández, A.F.; Viñes, F.; Illas, F. $\mathrm{CO}_{2}$ abatement by two-dimensional MXene carbides. J. Mater. Chem. A 2018, 6, 3381-3385. [CrossRef]

61. Gan, L.; Huang, D.; Schwingenschlögl, U. Oxygen adsorption and dissociation during the oxidation of monolayer Ti 2 C. J. Mater. Chem. A 2013, 1, 13672-13678. [CrossRef]

62. Xie, Y.; Naguib, M.; Mochalin, V.N.; Barsoum, M.W.; Gogotsi, Y.; Yu, X.; Nam, K.; Yang, X.; Kolesnikov, A.I.; Kent, P.R. Role of surface structure on Li-ion energy storage capacity of two-dimensional transition-metal carbides. J. Am. Chem. Soc. 2014, 136, 6385-6394. [CrossRef] [PubMed]

63. Kim, S.J.; Koh, H.J.; Ren, C.E.; Kwon, O.; Maleski, K.; Cho, S.Y.; Anasori, B.; Kim, C.K.; Choi, Y.K.; Kim, J. Metallic $\mathrm{Ti}_{3} \mathrm{C}_{2} \mathrm{~T}_{\mathrm{x}}$ MXene Gas Sensors with Ultrahigh Signal-to-Noise Ratio. ACS Nano 2018, 12, 986-993. [CrossRef] [PubMed]

(C) 2018 by the authors. Licensee MDPI, Basel, Switzerland. This article is an open access article distributed under the terms and conditions of the Creative Commons Attribution (CC BY) license (http://creativecommons.org/licenses/by/4.0/). 